\title{
Stressful Events in Autobiographical Memory Processing: Brazilian Version of the Centrality of Event Scale
}

\author{
Eventos Estressores no Processamento e Organização da Memória Autobiográfica: \\ Versão Brasileira da Escala de Centralidade de Evento
}

\author{
Gustavo Gauer ${ }^{*}, a$, Juliana Ávila de Souza ${ }^{a}$, André Madsen da Silveira $^{b}$ \\ $\&$ Cristina Yumi Nogueira Sediyama ${ }^{b}$ \\ ${ }^{a}$ Universidade Federal do Rio Grande do Sul, Porto Alegre, Brasil \\ $\&{ }^{b}$ Universidade Federal de Minas Gerais, Belo Horizonte, Brasil
}

\begin{abstract}
A stressful or traumatic event may become a central reference point in the organization of long-term memory, influencing the meaning of other experiences. The Centrality of Event Scale (CES) is an instrument in which participants recall the most traumatic event of their life and endorse 20 items. The CES was translated, adapted and validated for the Brazilian context in a sample of 195 undergraduates $(75.8 \%$ women). The version obtained good internal consistency and significant correlation with a screening measure of Post-Traumatic Stress Disorder symptoms. New hypotheses on the cognitive processing of traumatic events are explored in the light of a factor analysis of the CES. Opportunities for CES use include monitoring cognitive patterns and therapeutic effectiveness in situations related to trauma.

Keywords: Centrality of event, stress, trauma, memory, Post-Traumatic Stress Disorder.

Resumo

Um evento estressor ou traumático pode tornar-se um ponto de referência central na organização da memória de longo prazo, influenciando a significação das demais experiências. A Escala de Centralidade de Evento (ECE) é um instrumento em que o sujeito recorda o evento mais traumático de sua vida e endossa 20 itens respectivos. A ECE foi traduzida, adaptada e validada mediante aplicação em 195 estudantes universitários (75,8\% mulheres). Os resultados indicaram boa consistência interna e correlação significativa com rastreio de sintomas de estresse pós-traumático. Novas hipóteses explicativas do processamento cognitivo de eventos traumáticos são exploradas em resultados de uma análise fatorial exploratória. Oportunidades de aplicação da ECE incluem monitoramento de padrões cognitivos e efetividade terapêutica em situações relacionadas a trauma.
\end{abstract}

Palavras-chave: Centralidade de evento, estresse, trauma, memória, Transtorno de Estresse Pós-Traumático.

There is consensus in the psychological and neuropsychiatric literature about the fundamental role of emotion in the modulation of long-term memory (Erk, von Kalckreuth, \& Walter, 2010; McGaugh, 2003). The effects of emotion and stress on memory are well documented with data on the interactions between neurohormonal levels and cognitive performance (Wolf, 2008). At the

\footnotetext{
"Endereço para correspondência: Rua Ramiro Barcelos, 2600, sala 123, Porto Alegre, RS, Brasil 90035003. E-mail: gusgauer@gmail.com.

Este trabalho teve apoio financeiro do Conselho Nacional de Desenvolvimento Científico e Tecnológico $(\mathrm{CNPq})$, Fundação de Amparo à Pesquisa do Estado de Minas Gerais (FAPEMIG), Programa Santander Universidades e Universidade Federal de Minas Gerais (UFMG).

Os autores agradecem à Professora Dorthe Berntsen da Universidade de Aarhus (Dinamarca) e ao Professor David C. Rubin da Duke University (Durham, NC, EUA) pela autorização para elaborar a versão brasileira da CES.
}

neurohormonal level, stress causes the release of a set of endocrine substances known as stress hormones - mainly, cortisol, epinephrine and nor-epinephrine. The acute or chronic release of these hormones, in correlation with the body's stress response, interferes significantly in the physiology of the central and autonomic nervous system, especially in the hypothalamic-pituitary-adrenal axis (Labar \& Cabeza, 2006). In the realm of cognitive models, the effects of stress and trauma include an influence on assessments of cognitive representations of autobiographical events, greater availability of memories of significant events in situations of low and moderate stress, and significant damage to mnemonic abilities (e.g., intrusive memories, long-term overgeneralization, decreases in short-term memory capacity) resulting from acute or chronic traumatic situations (McNally, 2006).

In the general area of the cognitive processing of autobiographical events, the ability to recall, without effort, information relating to experiences in which the body 
was in danger or was successful is critical to adaptation (Damasio, 2010). However, the privileged process that ensures that information relevant to survival is prioritized, which is adaptive under normal circumstances, may become maladaptive in psychiatric disorders (Wolf, 2008). In the case of negative events, the memory-enhancing effect of those processing conditions can be especially harmful (Erk et al., 2010), to the extent that information about the events interacts with the identity or the sense of self.

Memories of negative events that are highly accessible for recovery may be frequently recalled, relived and ruminated upon (Berntsen \& Rubin, 2006). Traumatic experiences often change one's construction of the self, especially if a person suffers from persistent psychological effects as a result of the experience (Sutherland \& Bryant, 2005). Thus, negative experiences can become landmarks that organize the repertoire of experiences and autobiographical narratives. In this case, the impact of a past event tends to be continuous, to the extent that it has enormous potential to influence both the current interpretation of other experiences, even those not related to the trauma, and expectations for the future (Berntsen, Willert, \& Rubin, 2003). A recent descriptive model of this situation shows that stressful or traumatic experiences may come to occupy a central place in an individual's identity (Berntsen \& Rubin). In other words, representations of the traumatic episode occupy the position of the "center of narrative gravity" that characterizes the sense of self (Dennett, 1992).

Post-Traumatic Stress Disorder (PTSD), as defined in the DSM-IV (American Psychiatric Association [APA], 1994), is an anxiety disorder whose diagnostic criteria require that the condition be caused by a stressor event that occurred at least one month prior to diagnosis. There is evidence that the severity of the symptoms of PTSD is associated with negative evaluations, particularly evaluations of the self and the world (Moore, 2008). Examples of these judgments are propositions such as 'the world is dangerous', 'other people are dishonest' or 'one's own self is incompetent.' In a study using a paradigm of the retrieval of autobiographical memories by keywords, subjects with PTSD reported more trauma-related memories than individuals who had experienced potentially traumatic situations but did not develop PTSD (Moore). This finding suggests that traumatic memories are more accessible and inclusive than other memories. These changes may indicate that the trauma has increasingly become central to the subject's identity over time.

\section{Characteristics of Autobiographical Memories, Stress and Trauma}

In a study of 181 Danish individuals with PTSD symptoms, participants reported more vivid emotional recollections and sensory impressions of autobiographical memories. The most common perspective in these memories is that of the observer (seeing themselves "from the outside"), but the memories were not found to be fragmented. Participants also were likely to agree with the statement that the trauma had become part of their identity, and they perceived thematic connections between the trauma and the current events of their lives (Berntsen et al., 2003).

Rubin, Boals and Berntsen (2008) asked 533 North American college students to retrieve stressful memories, which were compared to neutral memories. Recollections of stressful memories and the severity of PTSD symptoms were related to memories with greater emotional intensity and were retrieved more frequently, either voluntarily or involuntarily. Overall, the stressful memories were not perceived by the subjects as being more fragmented than the other memories. Involuntary memories had more emotional intensity and less centrality to the life story than voluntary memories. Meeting the diagnostic criteria for PTSD had no effect, unlike the emotional response to events, which was higher in participants with PTSD symptoms. The interpretation of the results did not support the existence of a mechanism specific to traumatic memories, which could be explained by current models of the basic mechanisms of autobiographical memory applied to PTSD.

Participants with PTSD reported more self-defining memories related to trauma that had greater negative valence and were more intensely distributed in adulthood in comparison with participants without PTSD and control groups (Sutherland \& Bryant, 2005). Furthermore, the recovery of self-defining memories related to trauma was strongly associated with the reporting of personal goals that were related to the traumatic experiences. In another study, participants with PTSD had more specific memories of trauma in response to cues of positive memories than participants without PTSD. Furthermore, the recovery of traumatic memories was strongly associated with perceptions of the discrepancy between the actual self and the ideal self (Sutherland \& Bryant, 2007). A positive correlation was found between the centrality of traumatic memories and PTSD symptoms in soldiers who were in the Iraq war (Brown, Antony, Kramer, Root, \& Hirst, 2010). Although the centrality of trauma in the sample has been correlated with depression and dissociation, the centrality of the relationship between trauma and PTSD remained significant in a regression analysis of three predictor variables: the centrality of trauma, depression and dissociation.

\section{Centrality of the Memory in the PTSD}

Criterion A for PTSD diagnosis - exposure to a traumatic event outside the range of usual human experience - allows for the hipothesis that memory of the event feeds into the disorder. In fact, PTSD may be defined largely by the changes that occur specifically in autobiographical memory (Rubin, Boals et al., 2008). Patients may experience fragmented memories and intrusive memories related to the trauma. Due to those limitations, Rubin, 
Berntsen and Bohni (2008) have proposed a mnemonic model to explain PTSD and its symptoms. This model includes memory as its principal concept. The authors begin with the concept of constructive memory, in which the symptom is not derived from the event itself but from the memory of the traumatic event in the individual's life. That is to say, memory processes that lead to the emergence of PTSD provoke reactions mediated by memory. Events such as these that are processed and represented in memory would then be the central mechanism of causation rather than the event itself. The authors also suggest that factors such as gender, personality, social support, and individual history, which affect how the memory of the event and the emotions are encoded, maintained and retrieved, can change over time, affecting and being affected by the event. According to the mnemonic model, PTSD symptoms decrease when the evaluation of traumatic memory also decreases, suggesting that the symptoms increase when the availability of the traumatic memory increases. That is, the symptoms vary systematically with the availability of the traumatic event. According to the authors, some of the evidence that converges with this model suggests a low likelihood for PTSD to occur if the traumatic memory is unavailable, such as in cases of organic amnesia, infantile amnesia and pharmacologically induced amnesia.

\section{Event Centrality}

Although some people are affected by PTSD due to exposure to threatening events, other people who are exposed to events that are potentially just as traumatic do not develop the disorder. The difference may be the degree to which the traumatic memory, due to its specificity and personal meaning, becomes a milestone in the organization of autobiographical memory (Berntsen et al., 2003). Thus, a traumatic event may become a point of reference in the constitution of personal identity and the attribution of meaning to the other life experiences of the individual, making the traumatic memory highly accessible. This greater accessibility may explain why, in many cases, memories of traumatic events come to mind in a repeated and involuntary way.

The construct of event centrality is considered in terms of how a traumatic or highly stressful event becomes central to the life story and the identity of a person. The measure of centrality is significantly correlated with the severity of symptoms of posttraumatic stress disorder (Berntsen \& Rubin, 2006). From this perspective, stressful or traumatic events that become central to the way the subject understands himself or herself and the world and that interfere with the interpretations that he or she makes about new events are predictors of Post-Traumatic Stress Disorder (PTSD). The Centrality of Event Scale (CES) was developed to assess the centrality of a stressful event in an individual's personal experience.

Although the centrality of event measurement was first proposed in the context of modeling PTSD, it has poten- tial relevance in the overall study of the relationship between memory, emotion and self-representations in the personality. In a study of the CES, Pinto-Gouveia and Matos (2010) found correlations between core memories, specifically experiences of shame in childhood and adolescence, and current experiences of shame in adulthood.

The objective of this study was to explore possible relationships between event centrality and cognitive judgments oriented towards the past, present and future in the cognitive processing of memories related to traumatic or stressful events. To this end, the Centrality of Event Scale was adapted to the Brazilian context. The validation of the instrument includes an internal consistency analysis and convergent validation by correlation with the Screening for Posttraumatic Stress Symptoms (SPTSS). The specification of the relationship between event centrality and its representation and influence on the processes of judgments about the past, present and future of the life story are based on the exploratory factor analysis of the scale.

\section{Method}

\section{Participants}

The study included 195 undergraduates from a University in Belo Horizonte, MG, of which 148 (75.9\%) were women. The average age was 21.5 years $(S D=3.5)$, ranging from 17 to 45 years. The average years of schooling completed was $14(S D=2.7)$, ranging from 11 to 26 years. Sampling occurred on a voluntary basis through an invitation in the classroom to participate in a study on personal memories of stressful events.

\section{Instruments}

Socio-Demographic Questionnaire. The socio-demographic questionnaire was used to provide a description of the sample. This questionnaire consisted of nine questions. In addition to questions such as sex and the participant's course major, participants were also asked whether they had performed or engaged in psychotherapy and whether they had a habit of writing about their experiences in a diary or equivalent.

Centrality of Event Scale. The Centrality of Event Scale (CES) was developed by Berntsen and Rubin (2006) as a measure of the degree to which the memory of a stressful event is a point of reference for personal identity and the assignment of meaning to other experiences in the life of an individual. The instrument provides the following prompt to the participant: "Please think for a moment about the most stressful or traumatic event in your life and answer the following questions honestly and sincerely." The scale consists of 20 statements about the event, followed by a five-point scale, anchored with " 1 strongly disagree" and " 5 - totally agree." Items on the Centrality of Event Scale (CES) translated into Portuguese are in the appendix. The authors found that the instrument 
Gauer, G., Souza, J. A., Silveira, A. M. \& Sediyama, C. Y. N. (2013). Stressful Events in Autobiographical Memory Processing: Brazilian Version of the Centrality of Event Scale.

had a good level of internal consistency (Cronbach's alpha $=.94$ ) and followed procedures for convergent validity through a correlation with the Beck Depression Inventory (BDI) and the Post-Traumatic Stress Disorder Checklist (PCL), a screening measure for PTSD symptoms. The CES correlations in the original study were $.38(p<.01)$ with the PCL and .23 $(p<.01)$ with the BDI.

Screening for Post-Traumatic Stress Symptoms. At the time of data collection, there was no validated Brazilian version of the PTSD Checklist (PCL), the PTSD symptoms measure used by the authors of the original CES. Thus, a validated Brazilian version of the SPTSS was used. The SPTSS is a self-report measure comprising 17 items in which the individual responds how often $(0=$ never, $10=$ always) he or she has experienced each of the 17 items in the previous two weeks. The score is calculated by averaging the 17 items. The instrument was developed to correlate each item and one of the symptoms of the diagnostic criteria for PTSD in the DSM-IV (APA, 1994), which includes three clusters of symptoms: reliving or re-experiencing, avoidance/dissociation and increased arousal. Examples of the items are "I feel isolated and isolated from other people" and "I try not to think about things that remind me of something bad that happened to me." The SPTSS was translated and adapted for Brazilian culture by Kristensen (2005). The Brazilian version of the SPTSS showed adequate psychometric properties, with $\alpha=.85$. The original version was significantly correlated with the BDI and the Beck Anxiety Inventory (BAI) and had good sensitivity and specificity with the Structured Interview - Posttraumatic Stress Disorder (SI-PTSD).

\section{Procedure}

The present translation and adaptation of the CES was authorized by its authors. The first step of the study was the translation and adaptation of the original scale to Brazilian culture. A researcher proficient in English translated the original scale, and a professional translator retranslated it. Of all of the items in the CES, one appeared most sensitive to cultural nuances during the translation process: the original phrasing of item 14 included the idea of weaving a carpet, which is not familiar in the Brazilian context. That question was adapted to use the idea of a web as a substitute metaphor for a structure with a central point. Finally, the translation into Portuguese and the translation back to English were submitted to two additional researchers proficient in both languages for judgment. The questionnaires were applied collectively in the classroom, following the signing of a Statement of Informed Consent. The questionnaires were conducted in the following order: the Social Demographic Questionnaire, the SPTSS, and the CES. The average duration of the procedure was approximately 40 minutes. The study was approved by the Ethics Commitee of Universidade Federal de Minas Gerais (Belo Horizonte, MG).

\section{Results}

Internal Consistency and Descriptive Statistics of the CES

The internal consistency for the 20 items of the translated and adapted CES was high, $\alpha=.95$.The itemtotal correlations ranged between .55 and .76 , and the value of $\alpha$ for the scale did not increase with the exclusion of any of the items. The lowest average $(1.82, S D=1.11)$ was found for item 14: If I were to weave a carpet of my life, this event would be in the middle with threads going out to many other experiences ("Se a minha vida fosse representada como uma teia, este evento estaria no centro, com fios partindo dele para várias outras experiências" in the adapted version), and the highest (3.63, $S D=$ 1.36) was for item 4: This event can be seen as a symbol or mark of important themes in my life ("Este evento pode ser visto como um símbolo ou uma marca de aspectos importantes na minha vida" in the adapted version).

An abbreviated version of the CES was obtained by selecting the seven items with high correlations. The items obtained $(6,10,12,14,16,17$ and 18) were virtually the same as the abbreviated version of the original scale, except for item 3, which was replaced by item 14 in the current version. The indicators of internal consistency of the abbreviated scale $(\alpha=.89)$ and its correlation with the full scale of 20 items $(p=.89, p<.01)$ were satisfactory and similar to the results of the study of the creation of the original scale.

The CES total score was calculated by summing the 20 items of the scale. The sample mean of the CES score was $57.6(S D=19.83)$. The minimum score was 20 , and the maximum score was 92 , with quartiles of $41,59.5$, and 74. No statistically significant difference was found when comparing the averages for women on the CES ( $M$ $=58.13, S D=19.33)$ and men $(M=56.27, S D=21.46)$. The score on the CES did not correlate significantly with age, the participants' years of schooling, or the age of the memory calculated by the elapsed time (in months) between the date of the stressful event, as estimated by the participant, and the testing date. Of the 195 participants, 54 did not provide estimated dates for the occurrence of the stressful event to allow the elapsed time to be calculated in months. The 141 stressful events with calculable estimated dates occurred, on average, 56.96 months ( $S D$ $=55.24$ ) before the testing day. High variability of the age of autobiographical memories of events is commonly observed in studies with personal recollections of events in which the temporal criterion of choice is not limited by the order of the task (Gauer \& Gomes, 2008).

\section{Event Centrality and Screening of PTSD Symptoms}

Convergent validity of the CES was measured by correlation with the screening for PTSD, as measured by the SPTSS. There was a low but significant correlation $(.25, p<.01)$ between the event centrality and the PTSD screening. Participants had a mean score of 3.18 on the 
SPTSS, ranging from a minimum of 7 to a maximum of 7.29. Although standard data for the SPTSS are not available as a criterion for the diagnosis of PTSD in Brazil, it is notable that an international study (Caspi, Carlson, \& Klein, 2007) found a cutoff point for diagnosis of PTSD of an SPTSS score above 7.41.

\section{Principal Components Factor Analysis of the CES}

A principal component analysis (PCA) with a Varimax rotation showed three components with eigenvalues above 1. Component 1 grouped items 1, 2, 3, 4, 6, 7, 8, 9, 10 and 12. Component 2 grouped items 5, 11, 14, 15, 16, 18 and 19. Component 3 grouped items 13, 17 and 20.
The eigenvalues and percentages of explained variance were 10.10 and $50.49 \%$ (component 1 ), 1.28 and $6.42 \%$ (component 2) and 1.11 and $5.56 \%$ (component 3 ). The data were adequately relevant to the model, with a KMO coefficient of .94. The factor loadings of the items of the three CES components are presented in Table 1. Based on the criteria for the retention of items with loads higher than .45 , almost all items showed a clear pattern of clustering in a single component. The exception was item $7, I$ believe that people who have not experienced an event like this think differently than I think, which had loadings of .46 and .43 , respectively, for component 1 and component 2 .

Table 1

Items in the Brazilian Version and Respective Factor Loadings from a Principal Component Analysis with Varimax Rotation $(n=195)$

Item $\quad$\begin{tabular}{lll}
\cline { 2 - 3 } \\
\hline
\end{tabular}

1) Este evento tornou-se um ponto de referência para a maneira como eu compreendo novas experiências

2) Automaticamente, eu vejo conexões e semelhanças entre este evento e outras experiências em minha vida atual (2)

6) Este evento tornou-se um ponto de referência na forma como eu entendo a mim mesmo e ao mundo * $\quad .72$

12) Este evento alterou a maneira como eu penso e me sinto sobre outras experiências * $\quad .72$

9) Frequentemente eu vejo conexões e semelhanças entre este evento e meus relacionamentos atuais com outras pessoas $\quad .72$

8) Este evento diz muito sobre quem eu sou $\quad .69$

4) Este evento pode ser visto como um símbolo ou uma marca de aspectos importantes na minha vida $\quad .62$

3) Eu sinto que este evento tornou-se parte de quem eu sou $\quad .56$

10) Eu sinto que este evento tornou-se uma parte central da história da minha vida * .51

7) Eu acredito que pessoas que não experimentaram um evento como este pensam diferentemente do que eu penso

16) Este evento mudou permanentemente a minha vida *

15) A história da minha vida pode ser dividida em dois capítulos principais: um capítulo antes deste evento, e o outro, depois deste evento

$\begin{array}{ll}\text { 5) Este evento está fazendo minha vida ser diferente da maioria das outras pessoas } & .67 \\ 18) & \text { Este evento foi um ponto de mudança na minha vida * }\end{array}$

19) Se este evento não tivesse acontecido comigo, eu seria uma pessoa diferente hoje em dia $\quad .60$

11) Eu acredito que pessoas que não experimentaram este tipo de evento têm uma maneira de ver a si mesmas diferente da maneira que eu vejo a mim mesmo

14) Se a minha vida fosse representada como uma teia, este evento estaria no centro, com fios partindo dele para várias outras experiências *

20) Quando eu penso sobre meu futuro, eu frequentemente me remeto a este evento

17) Eu penso com frequência sobre os efeitos que este evento terá no meu futuro *

13) Este evento tornou-se um ponto de referência para a maneira como eu olho para o futuro

Eigenvalue

Percentage of variance explained

Number of items in the component

Cronbach's Alpha

$\begin{array}{ccc}10.10 & 1.28 & 1.11 \\ 50.49 & 6.42 & 5.56 \\ 10 & 7 & 3 \\ .89 & .89 & .81\end{array}$

Note. Only loadings above .45 are depicted; $\left(^{*}\right)=$ Items in the CES short version. 


\section{Discussion}

Properties of the CES and Stressful or Traumatic Events

This study presented a non-clinical sample with an instrument to measure centrality, a new construct, which is hypothesized to be correlated with the cognitive processing of stressful and traumatic events as well as symptoms of PTSD. The interpretation shows a significant but low correlation with the SPTSS, with convergent validity between related components. The SPTSS is a screening measure of symptoms with high sensitivity for the diagnosis of PTSD (Carlson, 2001), a property suitable for screening. The sample analyzed here was not clinical. Although there are no data on the PTSD diagnosis, it is fair to infer that the presence of participants with the disorder was relatively low based on the prevailing data, which indicates a prevalence of PTSD of 5\% to $10 \%$ in the general population. Moreover, the estimated prevalence of the occurrence of major stressful events in the general population is $40 \%$. Despite the absence of a variable criterion to indicate the presence of PTSD through diagnostic interview or self-diagnostic information from the participants, the data presented here provide evidence of the validity of the Centrality of Event Scale as a measurement tool. The contribution of the construct of centrality in monitoring cognitive processing in the presence of PTSD has demonstrated convergent validity with measures of symptoms of the disorder, a result replicated in this study. The results reported here may also contribute to the description of the processing of information related to stressful or traumatic events in the general population.

The Processing of Stressful or Traumatic Events: Indicators of the Factor Structure of the CES

In the original CES article, Berntsen and Rubin (2006) stressed the unifactoriality of the scale, with a 9.38 eigenvalue for the first factor. The first factor eigenvalue was even higher in the present version of the scale (10.10), which contributes to support the potential unifactoriality of the construct. However, we here opted to explore possible underlying processes that characterize centrality of event processing in the organization of autobiographical memory, by considering in detail the three-factor solution.

The first component identified in the PCA grouped ten items of the CES. In terms of their semantic content, the grouped items refer generally to the effect of the traumatic event as a reference point for the personal identity and influence processes of perception, reasoning and the significance of current experiences. Thus, the interpretation of the component as a reference point is proposed: the memory of a potentially traumatic event has become a reference point for cognitive judgments about the individual's present experience. Another possible interpretation related to the effects of stressful and/or traumatic events on the process of judging and reasoning is that the prominence that the event acquires makes it a highly available way to make judgments about representations of current events.

The second component grouped seven items. Six of the items in this component relate to changes in the participants' lives arising from the event (e.g., life is split into before and after the event) or the difference between what the individual identifies in his or her own life and the lives of other people as a result of the experience (people who did not experience the event see the world differently than what the participant sees). The items with lower loadings for the component refer to the organization of life into a web of lines leading out from the event. The semantic content of the items indicates that the event makes the individual's experience unique or distinct from the experiences of others who have not undergone this event. In this sense, the traumatic event imposes a characteristic of singularity on the individual's experience. To judge one's experiences in contrast to others, even hypothetically, these experiences must have already occurred. Therefore, the component refers to past experience contrasted with present experiences and in comparison with the experiences of others. Due to the prominent availability of the stressful event, the individual departs from the past event, which has become a point of reference, to deduce the consequences of the event and to estimate the specificity of the situation in comparison with others who did not experience such an event.

The third component grouped items 13,17 and 20. All of the respective statements refer to the influence of the traumatic event for current judgments that the individual makes about the future. The semantic commonality of the items points to the individual's formulation of the expected consequences of the event for the future. In this case, the judgment influences the likelihood of a new occurrence of the event by simulating possible future consequences of the stressful or traumatic event. Thus, although the event belongs to the past, it continues to influence the individual's current perspective on evaluations and expectations of future events.

\section{Final Remarks}

The relationship between autobiographical memory and the cognitive processing of traumatic content suggests that memories of traumatic events have the potential to influence representations of identity by becoming selfdefining memories (Sutherland \& Bryant, 2005). In cases in which these memories trigger psychopathology, such as PTSD, they cause serious damage to the health of the individuals exposed to these stressful events. Whether as a healthy coping feature of stressful events or as the pathological cycle that characterizes PTSD, the relationship between the self and the repertoire of autobiographical experiences seems to be bidirectional (Sutherland $\&$ Bryant, 2007). Negative memories with high availability inform representations that are important to the self, 
such as goals. In turn, these goals can lead to repetitive thought patterns, such as rumination, fed by intrusive memories related to stressful events and monitored by a self whose processes and representations are themselves informed by those memories.

Specifically, the validity of the CES relates to the realization that it is not be the type of event but the event's patterns of organization in the repertoire of the subject's memory that leads to pathological outcomes such as PTSD (Rubin, Boals et al., 2008) or to healthy processing, as suggested in hypotheses of post-traumatic growth (Boals, Schuettler, \& Steward, 2010). In all cases, the impact of the event varies according to the individual's perception and evaluation of the event. In the context of positive psychology, psychopathology is viewed dimensionally; clinical problems and clinical populations differ only in the degree, not in the type, of normal life problems (Joseph \& Linley, 2008). Functional and dysfunctional psychological workings are located on a continuum of human functioning. PTSD symptoms, such as reliving, avoidance and arousal, are seen as continuous rather than dichotomous variables that are simply present or absent. These are not considered separate and distinct entities but rather extreme variants of normal psychological phenomena. In fact, symptoms of posttraumatic stress seem to arise in response to negative stressful events involving a wide range of emotions, even though these emotions do not meet the diagnostic criteria for PTSD. However, emotionally negative memories may become central to the self-understanding and worldview of the individual (Pinto-Gouveia \& Matos, 2010).

Future studies on the centrality of events in the organization of autobiographical memory and cognitive processing are encouraged in clinical and experimental contexts. In particular, it would be of interest to validate the CES with clinical populations to confirm its validity together with the criteria for anxiety and mood disorders to deepen the understanding of models of cognitive processing in PTSD. Furthermore, the applicability of the scale should be evaluated in the diagnosis, monitoring, treatment effectiveness, and psychotherapy techniques for disorders related to stress and trauma. In the context of experimental cognitive psychology, it would be interesting to use the CES, in combination with specific tasks, to investigate the relationships between memory, emotion and personal meanings related to the sense of self and the organization of autobiographical memory in narratives of events and normal life routines. The centrality of events can be explored as a key variable in the organization of autobiographical memory.

\section{References}

American Psychiatric Association. (1994). Manual diagnóstico e estatístico de transtornos mentais: DSM-IV(4. ed.). Porto Alegre, RS: Artes Médicas.
Berntsen, D., \& Rubin, D. C. (2006). The Centrality of Event Scale: A measure of integrating a trauma into one's identity and its relation to post-traumatic stress disorder symptoms. Behaviour Research and Therapy, 44, 219-231.

Berntsen, D., Willert, M., \& Rubin, D. C. (2003). Splintered memories or vivid landmarks? Qualities and organization of traumatic memories with and without PTSD. Applied Cognitive Psychology, 17, 675-693.

Boals, A., Steward, J. M., \& Schuettler, D. (2010). Advancing our understanding of posttraumatic growth by considering event centrality. Journal of Loss and Trauma, 15, 518-533.

Brown, A. D., Antonius, D., Kramer, M., Root, J. C., \& Hirst, W. (2010). Trauma centrality and PTSD in veterans returning from Iraq and Afghanistan. Journal of Traumatic Stress, 23, 496-499.

Carlson, E. B. (2001). Psychometric study of a brief screen for PTSD: Assessing the impact of multiple traumatic events. Assessment, 8, 431-441.

Caspi, Y., Carlson, E. B., \& Klein, E. (2007). Validation of a Screening Instrument for Posttraumatic Stress Disorder in a Community Sample of Bedouin Men Serving in the Israeli Defense Forces. Journal of Traumatic Stress, 20, 517-527.

Damasio, A. R. (2010). Self comes to mind: Constructing the conscious brain. New York: Pantheon.

Dennett, D. C. (1992) The self as a center of narrative gravity. In F. Kessel, P. Cole, \& D. Johnson (Eds.), Self and consciousness: Multiple perspectives (pp. 103-115). Hillsdale, NJ: Erlbaum.

Erk, S., von Kalckreuth, A., \& Walter, H. (2010). Neural longterm effects of emotion regulation on episodic memory processes. Neuropsychologia, 48, 989-996.

Gauer, G., \& Gomes, W. B. (2008). Recordação de eventos pessoais: Memória autobiográfica, consciência e julgamento. Psicologia: Teoria e Pesquisa, 24(4), 507-514.

Joseph, S., \& Linley, F. A. (2008). Positive psychological perspectives on posttraumatic stress: An integrative psychosocial framework. In S. Joseph \& F. A. Lilney (Eds.), Trauma, recovery, and growth: Positive psychological perspectives on posttraumatic stress (pp. 3-20). Hoboken, NJ: Wiley.

Kristensen, C. H. (2005). Estresse pós-traumático: Diagnóstico, prevalencia e funcionamento cognitivo. (Tese de Doutorado não-publicada). Universidade Federal do Rio Grande do Sul, Porto Alegre, RS.

LaBar, K. S., \& Cabeza, R. (2006). Cognitive neuroscience of emotional memory. Nature Reviews: Neuroscience, 7, 54-64.

McGaugh, J. L. (2003). Memory and emotion: The making of lasting memories. London: Weidenfeld \& Nicolson.

McNally, R. J. (2006). Cognitive abnormalities in post-traumatic stress disorder. Trends in Cognitive Sciences, 10(6), 271-277.

Moore, S. A. (2008). Cognitive abnormalities in posttraumatic stress disorder. Current Opinion in Psychiatry, 22, 19-24.

Pinto-Gouveia, J., \& Matos, M. (2010). Can shame memories become a key to identity? The centrality of shame memories predicts psychopathology. Applied Cognitive Psychology, 25(2), 281-290.

Rubin, D. C., Berntsen, D., \& Bohni, M. K. (2008). A memorybased model of posttraumatic stress disorder: Evaluating basic assumptions underlying the PTSD diagnosis. Psychological Review, 115, 985-1011.

Rubin, D. C., Boals, A., \& Berntsen, D. (2008). Memory in posttraumatic stress disorder: Properties of voluntary and involuntary, traumatic and non-traumatic autobiographical 
Gauer, G., Souza, J. A., Silveira, A. M. \& Sediyama, C. Y. N. (2013). Stressful Events in Autobiographical Memory Processing: Brazilian Version of the Centrality of Event Scale.

memories in people with and without PTSD symptoms. Journal of Experimental Psychology: General, 137(4), 591614.

Sutherland, K., \& Bryant, R. A. (2005). Self-deûning memories in post-traumatic stress disorder. British Journal of Clinical Psychology, 44, 591-598.

Sutherland, K., \& Bryant, R. A. (2007). Autobiographical memory and the self-memory system in Posttraumatic Stress Disorder. Journal of Anxiety Disorders, 22, 555-560.

Wolf, O. T. (2008). The inûuence of stress hormones on emotional memory: Relevance for psychopathology. Acta Psychologica, 127, 513-531. 